University of Nebraska - Lincoln DigitalCommons@University of Nebraska - Lincoln

USGS Staff -- Published Research

US Geological Survey

2015

\title{
The distribution of selected elements and minerals in soil of the conterminous United States
}

Laurel Woodruff

U.S. Geological Survey, woodruff@usgs.gov

William F. Cannon

U.S. Geological Survey

David B. Smith

U.S. Geological Survey

Federico Solano

U.S. Geological Survey

Follow this and additional works at: http:// digitalcommons.unl.edu/usgsstaffpub

Part of the Geology Commons, Oceanography and Atmospheric Sciences and Meteorology Commons, Other Earth Sciences Commons, and the Other Environmental Sciences Commons

Woodruff, Laurel; Cannon, William F.; Smith, David B.; and Solano, Federico, "The distribution of selected elements and minerals in soil of the conterminous United States" (2015). USGS Staff -- Published Research. 946.

http:// digitalcommons.unl.edu/usgsstaffpub/946

This Article is brought to you for free and open access by the US Geological Survey at DigitalCommons@University of Nebraska - Lincoln. It has been accepted for inclusion in USGS Staff -- Published Research by an authorized administrator of DigitalCommons@University of Nebraska - Lincoln. 


\title{
The distribution of selected elements and minerals in soil of the conterminous United States
}

\author{
Laurel Woodruff ${ }^{\text {a,*}}{ }^{\text {, William F. Cannon }}{ }^{\text {b }}$, David B. Smith ${ }^{\text {c }}$, Federico Solano ${ }^{\text {b }}$ \\ ${ }^{a}$ U.S. Geological Survey, 2280 Woodale Drive, St. Paul, MN 55112, USA \\ b U.S. Geological Survey, Mail Stop 954 National Center, Reston, VA 20192, USA \\ c U.S. Geological Survey, Mail Stop 973 Denver Federal Center, Denver, CO 80225, USA
}

\section{A R T I C L E I N F O}

\section{Article history:}

Received 12 February 2014

Revised 6 January 2015

Accepted 19 January 2015

Available online 24 January 2015

\section{Keywords:}

Soil geochemistry

Soil mineralogy

Trace elements

\begin{abstract}
A B S T R A C T
In 2007, the U.S. Geological Survey initiated a low-density ( 1 site per $1600 \mathrm{~km}^{2}, 4857$ sites) geochemical and mineralogical survey of soil of the conterminous United States as part of the North American Soil Geochemical Landscapes Project. Three soil samples were collected, if possible, from each site; (1) a sample from a depth of 0 to $5 \mathrm{~cm}$, (2) a composite of the soil A-horizon, and (3) a deeper sample from the soil C-horizon or, if the top of the C-horizon was at a depth greater than $100 \mathrm{~cm}$, from a depth of approximately $80-100 \mathrm{~cm}$. The $<2 \mathrm{~mm}$ fraction of each sample was analysed for a suite of 45 major and trace elements following near-total multi-acid digestion. The major mineralogical components in samples from the soil A- and C-horizons were determined by a quantitative X-ray diffraction method using Rietveld refinement. Sampling ended in 2010 and chemical and mineralogical analyses were completed in May 2013. Maps of the conterminous United States showing predicted element and mineral concentrations were interpolated from actual soil data for each soil sample type by an inverse distance weighted (IDW) technique using ArcGIS software. Regional- and national-scale map patterns for selected elements and minerals apparent in interpolated maps are described here in the context of soil-forming factors and possible human inputs. These patterns can be related to (1) soil parent materials, for example, in the distribution of quartz, (2) climate impacts, for example, in the distribution of feldspar and kaolinite, (3) soil age, for example, in the distribution of carbonate in young glacial deposits, and (4) possible anthropogenic loading of phosphorus $(\mathrm{P})$ and lead $(\mathrm{Pb})$ to surface soil. This new geochemical and mineralogical data set for the conterminous United States represents a major step forward from prior national-scale soil geochemistry data and provides a robust soil data framework for the United States now and into the future.
\end{abstract}

Published by Elsevier B.V.

\section{Introduction}

Soil is at the junction of the lithosphere, the biosphere, and the atmosphere, and has a critical role in all aspects of ecology and human existence. Soil supports food production, controls water storage and ground water recharge, and shapes the biogeochemical cycles for essential nutrients in the environment. Despite the vital status of soil, there has been a remarkable lack of information on soil geochemistry for soil collected and analysed with consistent protocols for much of the North American continent (Smith et al., 2013a). These data limitations were addressed by the North American Soil Geochemical Landscapes Project (NASGLP), a cooperative project among the national geological surveys of the United States, Mexico, and Canada (Friske et al., 2013; Smith et al., 2009, 2011, 2012). The objectives of the NASGLP were to (1) produce a soil geochemical and mineralogical database, and its representation in map form, for the continent of North America

\footnotetext{
* Corresponding author. Tel.: +1 763783 3291; fax: +1 7637833103 .

E-mail address: woodruff@usgs.gov (L. Woodruff).
}

(21 million square kilometres), (2) interpret observed geochemical and mineralogical patterns in terms of processes that caused those patterns, and (3) establish an archive of soil samples for use by future investigators. From 2007 to 2010, the U.S. Geological Survey (USGS) collected soil samples from 4857 sites throughout the conterminous United States as part of the NASGLP (Fig. 1A). The purpose of this paper is to use selected geochemical and mineralogical maps (areas outlined in Fig. 1B) to demonstrate broad-scale processes that control observed regional- and national-scale patterns of the distribution of elements and minerals in the different soil types of the conterminous United States.

\section{Methods}

All geochemical and mineralogical data for the conterminous United States were published by Smith et al. (2013b). This report (1) describes field sampling activities, sample preparation, and analytical methods, (2) gives details of the quality control protocols used to monitor the 


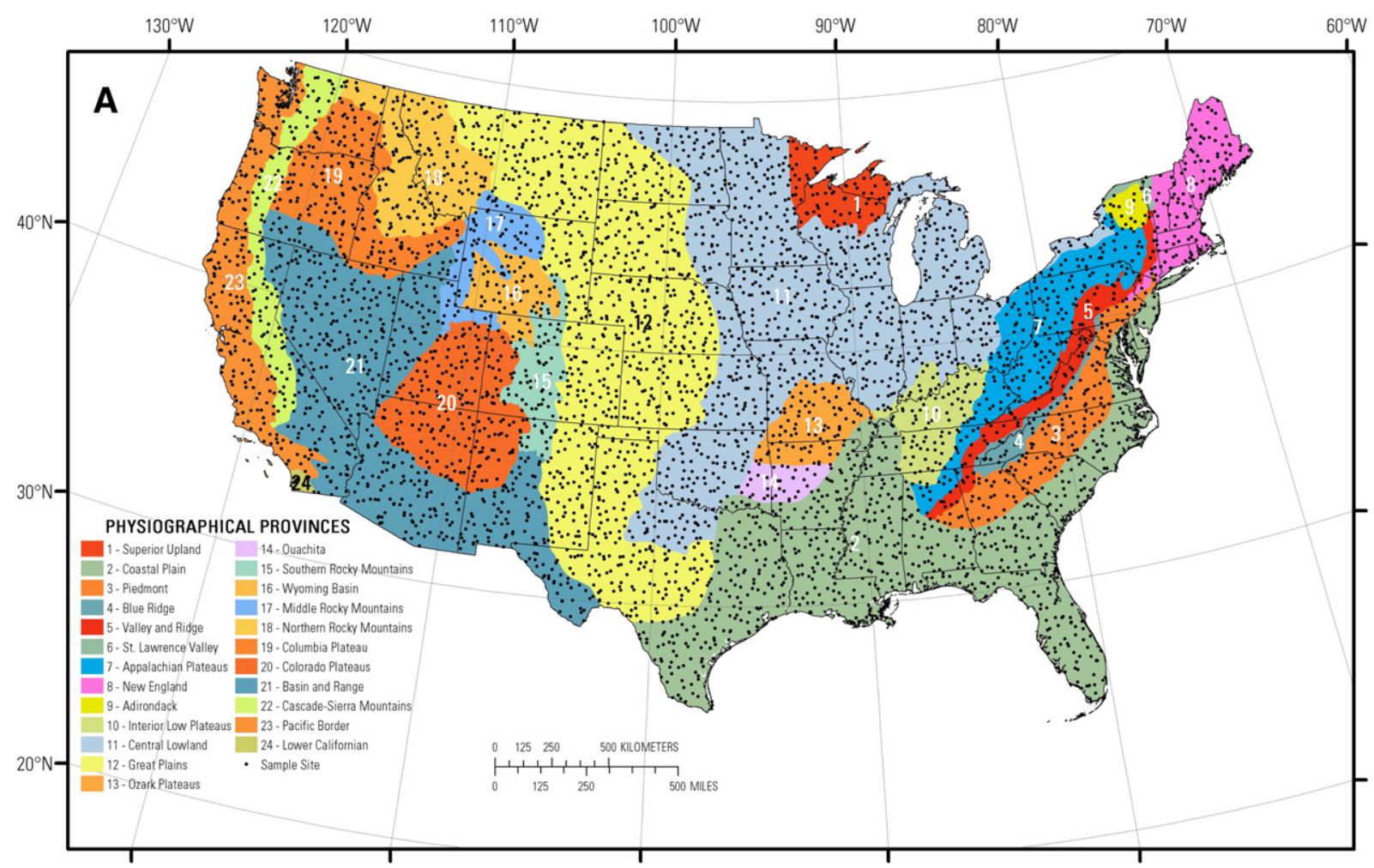

B

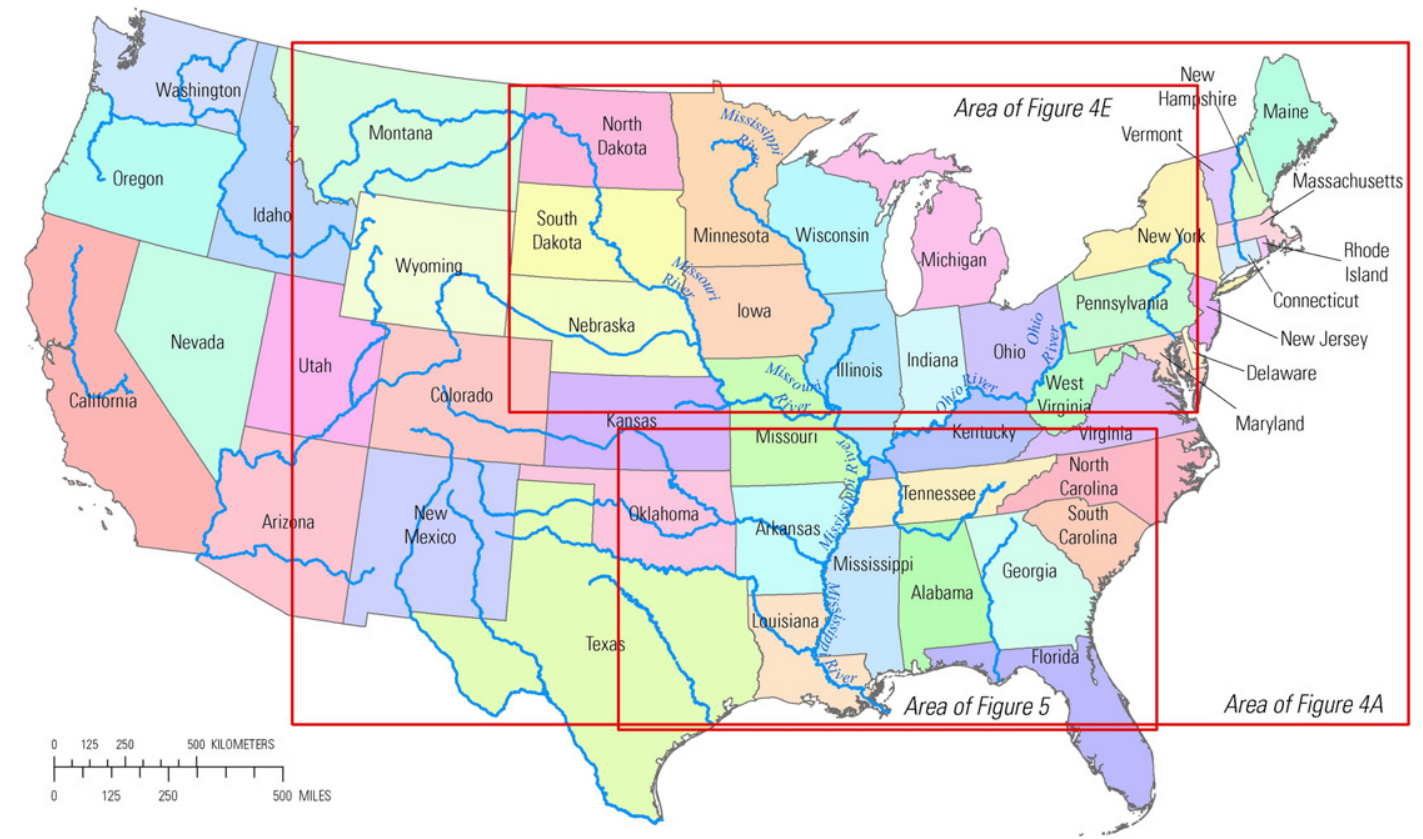

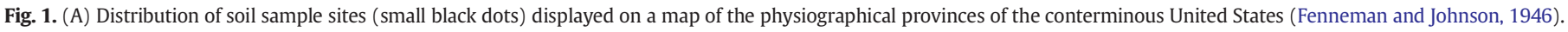
(B) Index map of the conterminous United States showing state names and major river systems (from www.nationalatlas.gov).

quality of chemical and mineralogical analyses generated over approximately six years, and (3) makes available the soil geochemical and mineralogical data. The report and analytical data are available for free download at http://pubs.usgs.gov/ds/801/. Interpolated maps showing the spatial distribution for each element and mineral and statistical summaries of all data are now available as a published report (Smith et al., 2014), and through an interactive web page http://mrdata.usgs. gov/soilgeochemistry/\#/summary. Only a brief overview of sampling protocols and analytical methods provided in Smith et al. (2013b) are given below.

\subsection{Soil sampling}

Sampling for the national-scale soil geochemical and mineralogical survey of the conterminous United States began in 2007 and was finished in 2010. Chemical and mineralogical analyses of the samples were completed in May 2013. Sample sites were selected on the basis of a generalised random tessellation stratified design (Stevens and Olsen, 2003, 2004) at a density of approximately 1 site per $1600 \mathrm{~km}^{2}$ (4857 sites for the conterminous United States) (Fig. 1B). This design produces a spatially balanced set of sampling points without adhering 
to a strict grid-based system. If an original target site was inaccessible for any reason during the sampling effort, the field crew would select an alternative site as close as possible to the original site with landscape and soil characteristics as similar to the original site as possible.

The sampling protocols used for the national-scale survey were a combination of depth-based and horizon-based sampling. Ideally, the following samples were collected at each site: (1) composited soil from a depth of 0 to $5 \mathrm{~cm}$, deemed especially important for human health considerations; (2) a composite of the soil A-horizon (the uppermost mineral soil); and (3) a sample from the soil C-horizon (generally partially weathered parent material) or, if the top of the C-horizon was deeper than $100 \mathrm{~cm}$, a sample from about 80 to $100 \mathrm{~cm}$. A comprehensive discussion of the sample site design and field sampling protocols is in Smith et al. (2013b).

\subsection{Geochemical analyses}

Each sample was air-dried at ambient temperature, disaggregated, and sieved to $<2 \mathrm{~mm}$. The $<2 \mathrm{~mm}$ material was then crushed to $<150 \mu \mathrm{m}$ prior to chemical analysis following near-total digestion in a low temperature mixture of hydrochloric, nitric, perchloric, and hydrofluoric acids. Concentrations of $\mathrm{Al}, \mathrm{Ca}, \mathrm{Fe}, \mathrm{K}, \mathrm{Mg}, \mathrm{Na}, \mathrm{S}, \mathrm{Ti}, \mathrm{Ag}, \mathrm{Ba}$, $\mathrm{Be}, \mathrm{Bi}, \mathrm{Cd}, \mathrm{Ce}, \mathrm{Co}, \mathrm{Cr}, \mathrm{Cs}, \mathrm{Cu}, \mathrm{Ga}$, In, La, Li, Mn, Mo, Nb, Ni, P, Pb, Rb, Sb, Sc, Sn, Sr, Te, Th, Tl, U, V, W, Y, and Zn were determined by inductively coupled plasma-atomic absorption spectrometry (ICP-AES), and inductively coupled plasma-mass spectrometry (ICP-MS) following the fouracid dissolution. Mercury was determined by cold-vapour atomic absorption spectrometry after dissolution in a mixture of nitric and hydrochloric acids. Arsenic was determined by hydride-generation atomic absorption spectrometry following fusion in a mixture of sodium peroxide and sodium hydroxide. Selenium was determined by hydridegeneration atomic absorption spectrometry after dissolution in a mixture of nitric, hydrofluoric, and perchloric acids. Total $\mathrm{C}$ was determined by use of an automated carbon analyser. The concentration of organic $C$ was calculated by subtracting the amount of inorganic (carbonate) $\mathrm{C}$ (determined from the mineralogical data for the carbonate minerals calcite, dolomite, and aragonite) from the total C concentration.

\subsubsection{Quality control protocols for geochemical analyses}

A comprehensive discussion of analytical methods, including quality control protocols, is given in Smith et al. (2013b) and summarised briefly here. This project followed four of the five recommended quality control (QC) procedures for geochemical mapping (Demetriades et al., 2014; Reimann et al., 2008, 2009, 2011, 2012). These four are (1) randomisation of samples prior to analysis, (2) insertion of international reference materials, (3) insertion of project standards, and (4) insertion of analytical duplicates of project standards. The fifth procedure that was not part of this project is collection and analysis of field duplicates. The pilot study for this project collected field duplicates as part of the sampling protocols (Smith et al., 2009). Based on an analysis of variance by Garrett (2009), it was determined that for this larger spatial project, collection of field duplicates would not improve the overall QC of the data.

The geochemical analyses received QC checks on three separate levels. For the first level, the USGS contract laboratory monitored QC by analysing a reference material (RM) with every batch of 48 samples. For the second level, the USGS QC officer inserted at least one RM between separate batches of 20 to 30 samples. At the third level, two blind RMs were inserted by the project manager (D.B. Smith, USGS) in each separate batch of 20 to 30 samples. Results from repeated analysis of two separate RMs indicated that, in general, there were no serious quality problems.

\subsection{Mineralogical analyses}

All soil A- and C-horizon samples were analysed by X-ray diffraction (XRD), and the percentages of major mineral phases were calculated using a Rietveld refinement method (Dreele, 1997; McCusker et al., 1999; Sakata and Cooper, 1979). Splits of the $<2 \mathrm{~mm}$ fraction were used for analysis. Zinc oxide (ZnO, $10 \mathrm{wt}$.\%) was added to each sample as an internal standard, which allows calculation of an amorphous component (this portion of the sample not quantified by the diffraction technique). The sample- $\mathrm{ZnO}$ mixture was ground for $3 \mathrm{~min}$ in isopropyl alcohol using a micronising mill and agate beads. Dried samples were disaggregated by passing through a $400 \mu \mathrm{m}$ sieve and lightly pressed into back-loaded sample mounts. Samples were analysed on a PANalytical X'Pert PRO Materials Research diffractometer using $\mathrm{Cu} \mathrm{K \alpha}$ radiation to collect digital data continuously from $3^{\circ}$ to $70^{\circ}$ $2 \theta$ (scan speed $=0.0567^{\circ} 2 \theta$ per second). PANalytical HighScore Plus software version 2.2a was used for pattern processing, mineral phase identification, and Rietveld quantitative mineral analysis.

\subsubsection{Quality control protocols for mineralogical analyses}

A comprehensive discussion of the QC protocols for the quantification of soil mineralogy is given in Smith et al. (2013b) and summarised briefly here. It is recognised that the highly weathered nature of many of the soil samples, and this selected method of quantification imposed some limitations on the analysis of clay phases, disordered clay phases, and amorphous components. The reliability of this method for common minerals was evaluated by analysing standard mixtures of pure mineral phases and standard mineral mixtures prepared in-house. Standards were inserted in each batch run of 45 unknowns to evaluate instrument drift. Additional standard mineral mixtures were analysed multiple times to evaluate mineral identification. Two duplicate samples were also analysed in each batch run of 45 unknowns. It was determined that the overall average accuracy reported with respect to absolute differences between actual and calculated percentages is $2 \%$.

\section{Results and discussion}

Soil by its very nature is anisotropic, developing vertical and lateral differences through pedogenetic processes. Soil geochemistry is determined by the original (inherited) mineralogy of the parent material and the transformations that these minerals may undergo during soil formation, as well as possible inputs from geogenic dust and human activities. Jenny's (1941) five soil-forming factors account for most of the differences in soil geochemistry and mineralogy across the conterminous United States. These five factors are: (1) parent material, (2) climate expressed as both precipitation and temperature effects, (3) topography, (4) time, and (5) organisms. Anthropogenic impacts on soil chemistry are included in this final factor, as humans have a profound influence on many facets of soil chemistry through activities, such as changes in land use and land cover, industrialisation, agriculture, mining and mineral processing, and urbanisation.

Many of the soil geochemical and mineralogical characteristics revealed by the new data of the conterminous United States can be interpreted in the context of landscape units related by common geographical or geological properties. These landscape units can share, for example, common topography, bedrock type and structure, and geological and geomorphological history (i.e., physiographical provinces as described by Fenneman and Johnson, 1946) or common land use, elevation and topography, climate, water, soil types, and vegetation (i.e., Major Land Resource Areas as described by United States Department of Agriculture and Natural Resources Conservation Service, USDA-NRCS, 2006). Information on the surficial geology for the conterminous United States that was used to determine soil parent materials is from Soller et al. (2009).

The interrelated effects of Jenny's (1941) five factors, and possible human impacts, are described in the sections below for selected aspects of the new soil geochemistry and mineralogy for the conterminous United States. Observed geochemical and mineralogical patterns are interpreted in terms of soil-forming processes that control vertical and spatial distribution. The maps used here to show predicted element 
and mineral concentrations across the United States were interpolated from the actual soil concentration data for each soil sample type by an inverse distance weighted (IDW) technique using ArcGIS software. The IDW method as applied here predicted unique concentration values for an array of grid cells, each of which covers an area of $444 \mathrm{~km}^{2}$, over the conterminous United States, determining an average concentration value for all data points within $75 \mathrm{~km}$ of the centre of each grid cell (Smith et al., 2014).

\subsection{Quartz}

Quartz in soil occurs as an inherited primary mineral from soil parent materials. Because of its resistance to weathering, the percentage of quartz increases in soil over time as less resistant minerals breakdown. Quartz concentration is one of the most significant variables in soil of the conterminous United States. It varies from 0.2 to $99.4 \mathrm{wt} . \%$ and quartz is, on average, the most abundant mineral in soil with a median concentration of $44.1 \mathrm{wt} . \%$ in the soil C-horizon. The map of quartz in the soil C-horizon (Fig. 2) shows large areas of distinctively high and low quartz concentration that can be related directly to soil parent materials. For instance, very high quartz concentration is a characteristic of soil along the eastern United States. The split outline for the Coastal Plain shown in Fig. 2 is taken from the Coastal Plain physiographical province outline (Fig. 1A), but cutting out the young alluvium and loess terraces of the Mississippi River and the Red River alluvium that cut through the older Coastal Plain. In general, soil within the Coastal Plain area is quartz-rich, excessively drained soil formed on Late Cretaceous to Holocene marine, predominantly clastic, sedimentary rocks, and aeolian deposits. Soil high in quartz also occurs in the Ozark Plateau physiographical province in the midcontinent where stony soil, largely composed of chert residuum in clay, is formed by deep weathering of cherty carbonate rock. The Colorado Plateau physiographical province in south-western United States is a region of mostly quartzose sandstone bedrock. Quartz-rich soil in this region is mostly formed on sandstone residuum and colluvium or from aeolian or alluvial deposits (Reynolds et al., 2006). Soil developed on aeolian sand in the Nebraska Sand Hills and in west Texas/eastern New Mexico also has high quartz concentrations. Within the glaciated portion of the country, especially high quartz concentrations along the western shore of Lake Michigan and the eastern Upper Peninsula of Michigan occur in areas of sandy glaciofluvial sediment and till. In contrast to these areas of high quartz, a prominent low in soil quartz concentration occurs in a large region of the north-western United States. In this area, soil is developed on mostly mafic igneous bedrock that has little or no primary quartz. Similarly, in the Edwards Plateau area of south-west Texas, soil is developed on limestone bedrock that also contains little primary quartz.

The quartz concentration of soil influences the distribution patterns of many other elements. Quartz contains essentially no elements other than silicon and oxygen, so that it acts to variably dilute other minerals that carry most of the elements that were determined. Twenty elements from the soil C-horizon (Al, Ga, Na, Sc, Fe, Mg, V, Be, Ba, Sr, Y, K, P, Co, Ca, $\mathrm{Tl}, \mathrm{Li}, \mathrm{Rb}, \mathrm{Nb}$, and $\mathrm{Zn}$, listed in order from highest to lowest negative correlations) show significant negative correlation with quartz concentration, indicating that this inverse quartz relationship will necessarily appear as part of their distribution patterns on national-scale maps. Thus, the spatial distribution of these elements is, in part, controlled by processes that concentrate or dilute quartz rather than processes related to the geochemical behaviour of these elements themselves. It is important when interpreting the cause of geographical variation of many elements to assess what portion of that variability is caused solely by this 'quartz effect' (Bern, 2009).

\subsection{Feldspar, kaolinite, and climate}

The interplay of moisture and temperature is a major factor in determining soil characteristics, and these climate effects are strongly imprinted on the distribution of many elements and minerals across

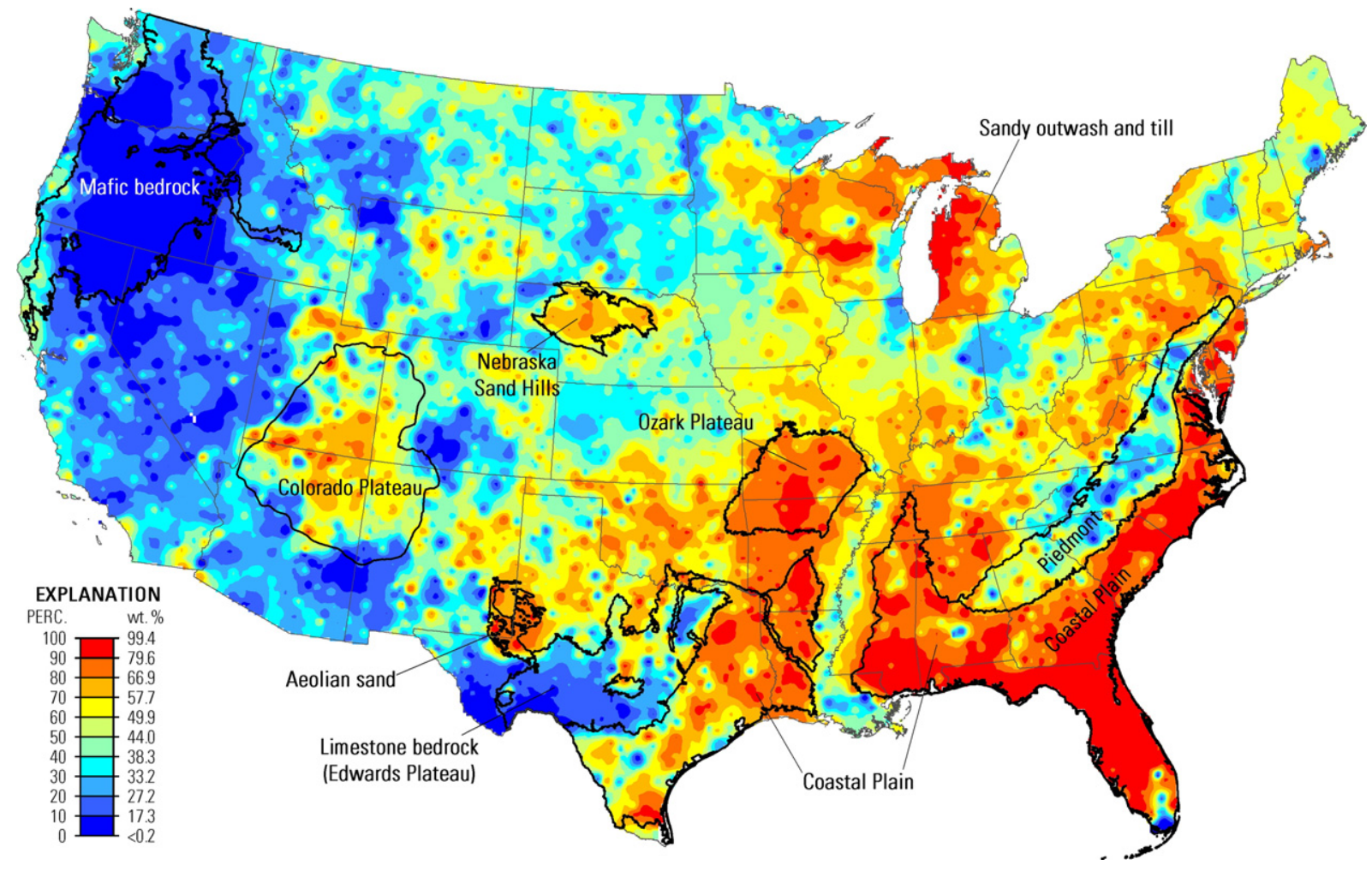

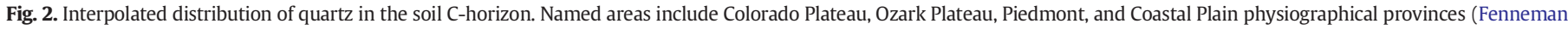

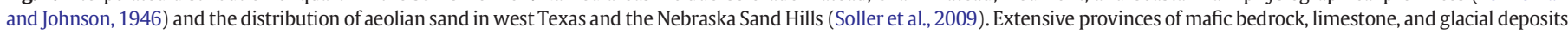
(outwash and till) are also indicated. Notation: Perc = percentile; wt.\% = weight percent. 
the conterminous United States. A broad, rather uniform, gradient in average annual precipitation extends across nearly two thirds of the United States from low precipitation east of the Rocky Mountains to higher precipitation to the east and south-east. Annual precipitation varies about five-fold along this gradient (Fig. 3A). A second, much sharper gradient in the north-western United States separates hyperhumid areas along the west coast from a drier, less humid climate inland. The boundary between these two climate regimes lies along the crest of the Cascade Range and the Sierra Nevada Mountains, where annual precipitation varies by ten-fold or greater between the western and eastern flanks of these ranges. Both this broad national precipitation gradient, and the more local west coast precipitation gradient, are strongly expressed in soil composition as illustrated in examples given below.

One of the most fundamental changes in soil composition across the United States is the weathering of feldspar in soil from west to east and south-east along the gradient of increasing precipitation from the Rocky Mountains to the east coast. Fig. 3B shows the distribution of total feldspar (total plagioclase + total potassium feldspar) in the soil A-horizon. Feldspar minerals are very reactive in the soil environment, typically breaking down in humid regions by hydrolysis and leaching to form the clay mineral kaolinite $\left(\mathrm{H}_{4} \mathrm{Al}_{2} \mathrm{Si}_{2} \mathrm{O}_{9}\right)$, while releasing $\mathrm{Ca}, \mathrm{Na}$, or $\mathrm{K}$ cations into solution. Feldspar, prevalent in soil, sourced from metamorphic and igneous rocks in the western United States, gives way to soil in the eastern United States formed from similar parent materials from which the original feldspar has been largely to totally obliterated by weathering in a more humid climate. For example, soil in the Piedmont physiographical province is developed from saprolite formed on crystalline Precambrian and Palaeozoic metamorphic and igneous, largely granitic, rocks. Piedmont soil types are deeply weathered and most feldspar has been altered to kaolinite, and Al-rich clay (Fig. 3C). The mineral gibbsite $\left[\mathrm{Al}(\mathrm{OH})_{3}\right]$ is an end product for intense chemical weathering, and all occurrences correlate with high kaolinite concentrations (Fig. 3C). Gibbsite is detected in soil from the Piedmont where intense weathering has modified kaolinite to gibbsite by loss of silica. In the north-western United States, the extreme climate variability from the coast to the interior mountain ranges forms a very sharp precipitation gradient (Fig. 3A), so that the gradual changes in soil mineralogy and chemistry observed in the eastern half of the United States are compressed along comparably sharp gradients. These changes are expressed as lower feldspar and higher clay concentration, especially kaolinite, in the coastal, higher precipitation areas, as well as lower concentrations of $\mathrm{K}, \mathrm{Na}, \mathrm{Ba}$, and other elements common in feldspar (Fig. 3C, $\mathrm{D}, \mathrm{E})$. As in the Piedmont, the intensity of weathering has been sufficient in some areas to produce extremely aluminous soil marked by the appearance of gibbsite (Fig. 3C).

This loss of feldspar in soil is expressed not only mineralogically by transformation of feldspar to kaolinite and then to gibbsite, but chemically in the leaching of nearly all major and trace elements present in the feldspar structure. Prime examples are the major elements $\mathrm{K}$ and $\mathrm{Na}$ (Fig. 3D, E) and the trace element Ba (Fig. 3F), all of which become successively depleted in soil from west to east, duplicating the feldspar pattern. The area of feldspar-depleted soil is of generally low to moderate relief, so that long-term weathering under humid conditions and low erosion rates forms large areas of very mature saprolitic soil, depleted in most easily leached elements. Although the Piedmont has complex bedrock geology providing highly variable soil parent materials, the effect of this parent material compositional variability is suppressed by the effects of intense chemical weathering. The importance of climate versus parent material is revealed in the mineralogy and chemistry of soil in the Piedmont and soil in the adjacent Coastal Plain. Soil types in both regions are developed under similar climate regimes, but with strongly contrasting parent materials. Soil in the Piedmont typically has high secondary kaolinite concentrations, whereas soil in the Coastal Plain is dominated by primary quartz (Markevich et al., 1990).

\subsection{Effects of Wisconsinan glaciation}

Much of Canada and about 15\% of the northern conterminous United States was covered by the Pleistocene Laurentide Ice Sheet (Fig. 4A). In the Upper Midwest melting of glacial ice following multiple late Wisconsin-period advances (16,000 to 12,000 years ago; Dyke et al., 2002; Mickelson and Colgan, 2003) left the region mantled with a blanket of mixed, immature sediments from which present day soil developed. Soil that developed on these young glacial sediments has distinctive mineralogy and chemistry compared to soil beyond the glaciated region. The relatively short time for soil development results in soil that commonly has high concentrations of easily weathered minerals, such as carbonates and related elements (for example, Ca and $\mathrm{Mg}$ ), which typically are missing in older, highly developed soil. A number of trace elements unrelated to carbonate minerals, including $\mathrm{Be}, \mathrm{Bi}$, Cs, La (Fig. 4B), Ni, Th, and Ti also have sharp gradients in concentration across the southerly glacial limit, with generally lower concentration in soil within the glaciated region compared to areas beyond the southerly glacial limit, because of the abrupt change in parent materials and soil age.

The provenance of transported glacial sediments is a combination of near and distant bedrock lithologies, which in some cases can form patterns of element and mineral concentrations in soil disconnected from underlying bedrock. Carbonate- and shale-rich 'grey' till in Minnesota, North Dakota, South Dakota, and Iowa, deposited by the Des Moines and James ice lobes, was derived from Cretaceous sedimentary rocks (dolostone, limestone, grey shale). This carbonaterich till was transported significant distances to the south and south-east from its source, and deposited on Precambrian bedrock that is devoid of carbonate minerals. In central Minnesota, northern Wisconsin and upper Michigan 'red' quartz- and feldspar-rich till of the Rainy and Superior lobes has a Precambrian granite/basalt/red sandstone provenance. In the lower Great Lakes region, carbonatebearing till sourced from more local dolostone, limestone, and black shale was deposited by the Green Bay and Lake Michigan ice lobes in western Wisconsin and northern Illinois (Johnson, 1986), and by the Erie-Huron ice lobe in eastern Indiana and western Ohio (Hofer and Szabo, 1993). One consequence of this glacial dispersal and minimal weathering of these young soil types is a large area that retains inherited carbonate minerals (Fig. 4C). Calcite is more common in soil developed on grey till of the Dakotas and western Minnesota, whereas soil developed on till in eastern Wisconsin and northern Illinois is characterised by high dolomite concentration relative to calcite concentration. One consequence of this high dolomite concentration is that dolomite-bearing soil in this area has some of the highest soil Mg concentrations in the United States (Fig. 4D).

The influence of a shale component on soil chemistry is illustrated by the distribution of Mo in soil from glaciated areas. Elevated Mo concentrations for soil developed on the Des Moines lobe and James lobe deposits contrast with much lower Mo concentrations in soil developed on till and outwash sourced from the Rainy and Superior lobes (Fig. 4E). This difference in Mo concentrations can be attributed to the presence of shale clasts in grey till compared to a lack of shale in red till. In the lower Great Lakes, the Green Bay lobe and adjacent Lake Michigan lobe, and the Saginaw lobe and adjacent Erie-Huron lobe, have Devonian black shale in the glacial provenance. Because of this black shale contribution, large areas of northern Ohio and Indiana have higher Mo concentrations than soil developed on grey till, as well as much of the rest of the conterminous Untied States (Fig. 4E). Other elements enriched in soil across this area include $\mathrm{As}, \mathrm{Cd}, \mathrm{Co}, \mathrm{Sb}$, $\mathrm{U}$, and $\mathrm{Zn}$, all of which may be enriched in this Devonian shale (Tuttle et al., 2009). Soil geochemistry and mineralogy across the glaciated Upper Midwest attest to the widespread impact on soil composition that dispersal of materials originating from different bedrock sources can have. 


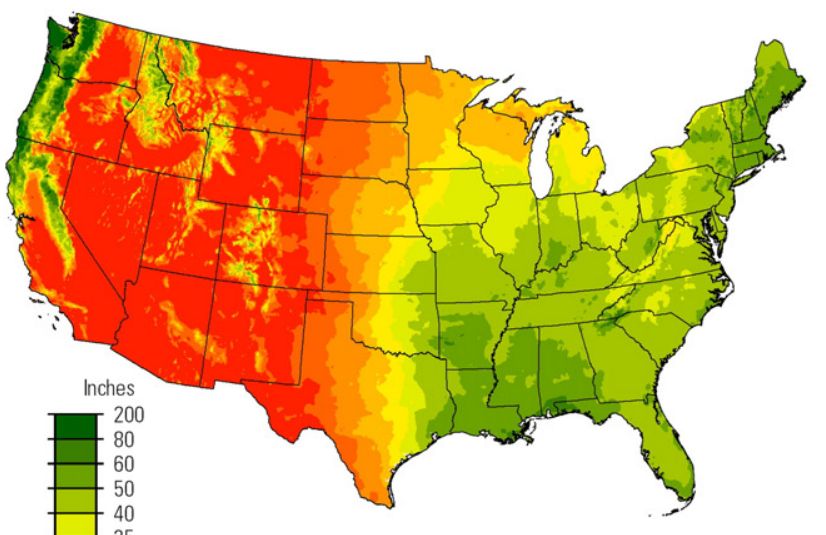

A. Average annual precipitation
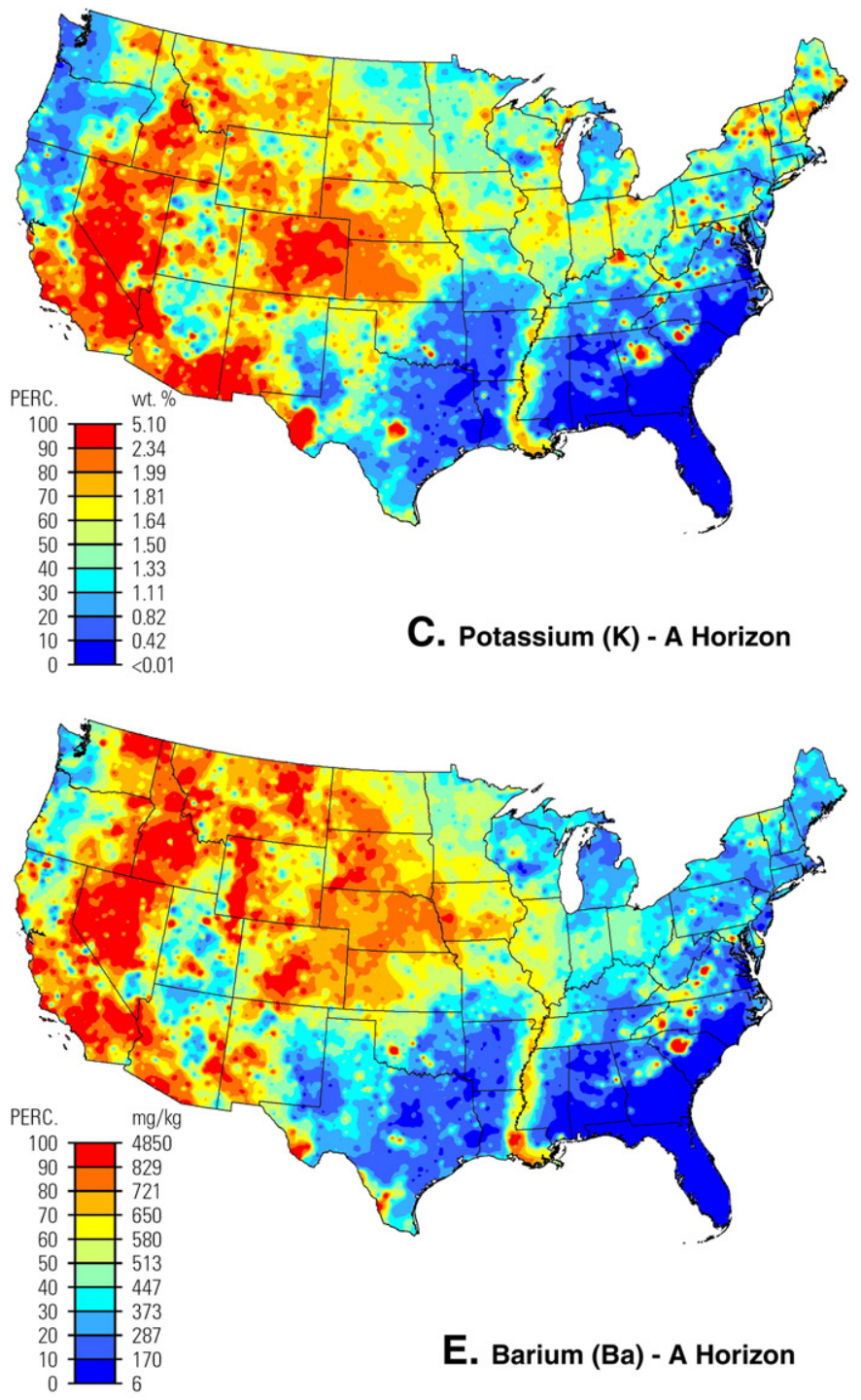
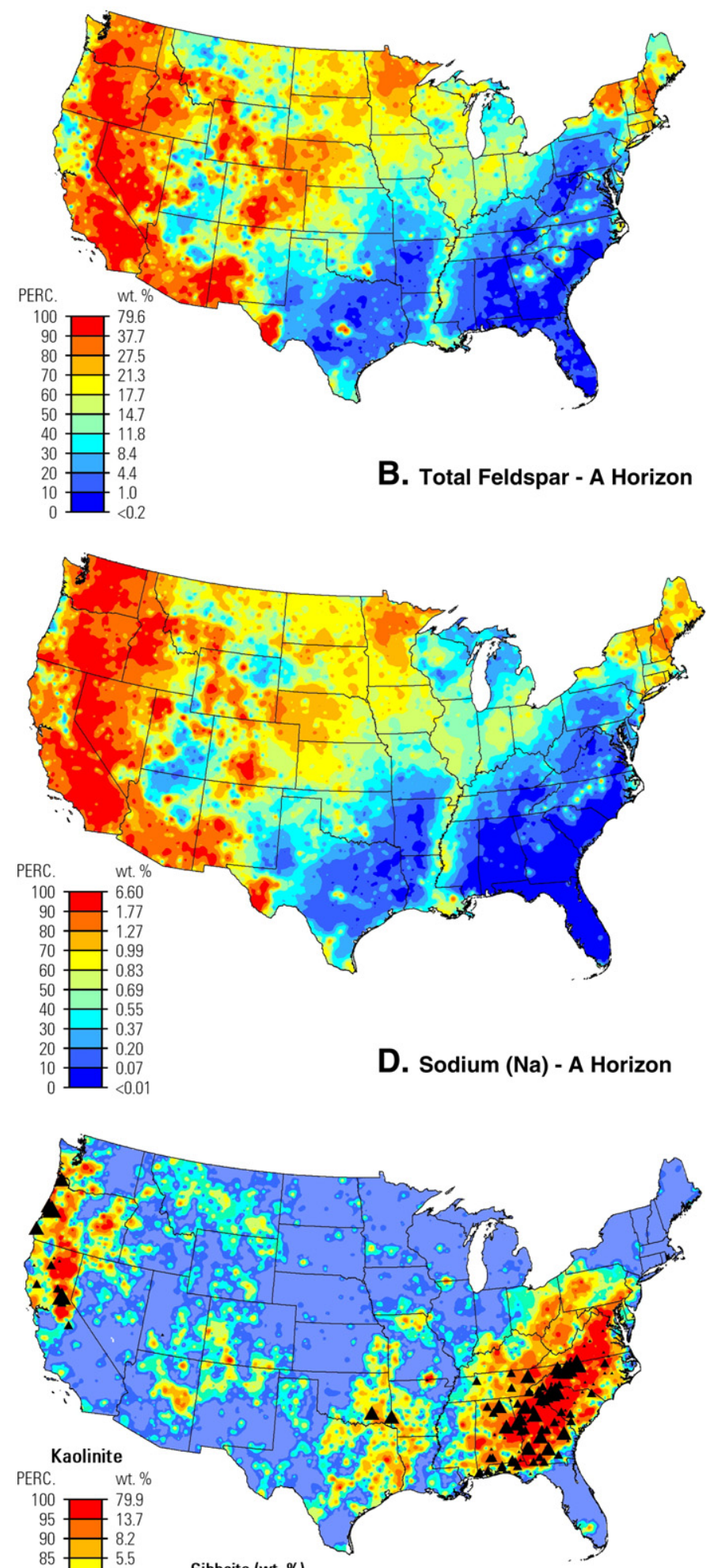

Gibbsite (wt. \%)

- $0.2-4.3$

- $4.4-8.5$

A $8.6-15.7$

A $15.8-30.4$

\section{F. Kaolinite and Gibbsite C Horizon}

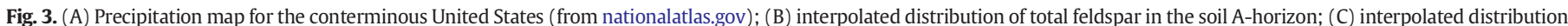

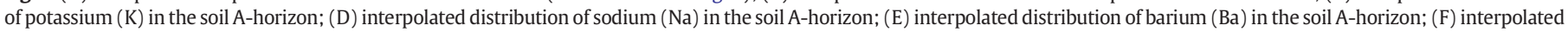

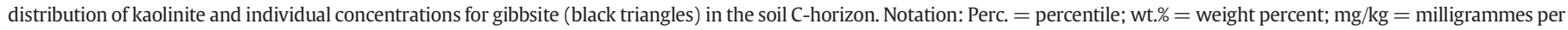
kilogramme. 


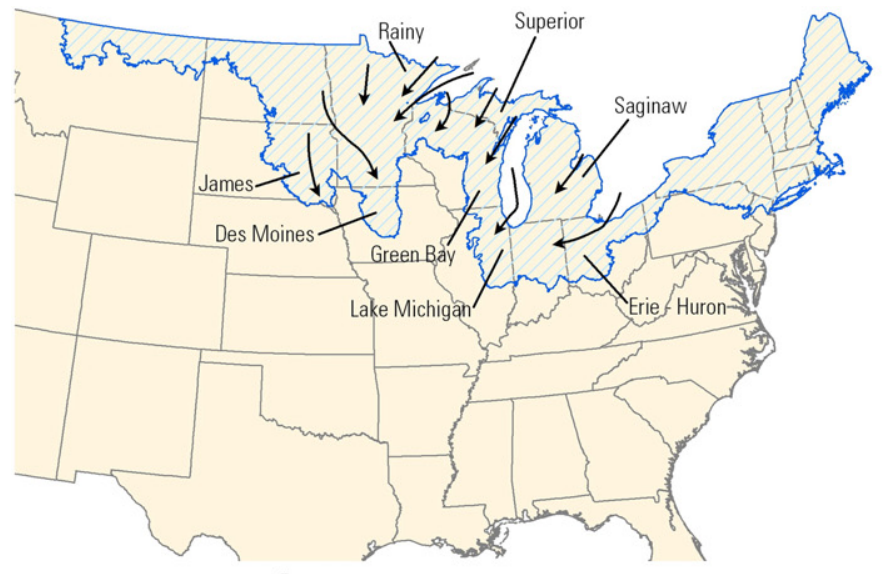

A. Extent of glaciation and glacial lobes

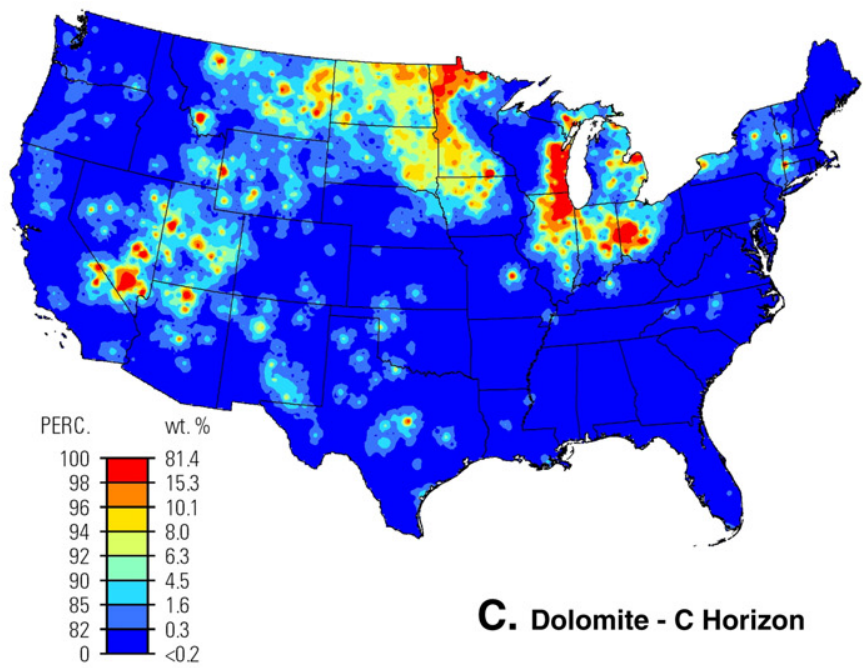

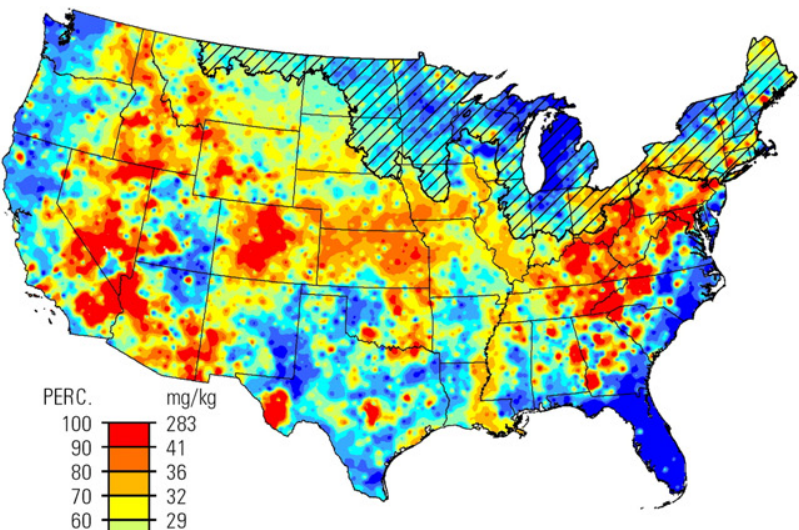

B. Lanthanum (La) - C Horizon

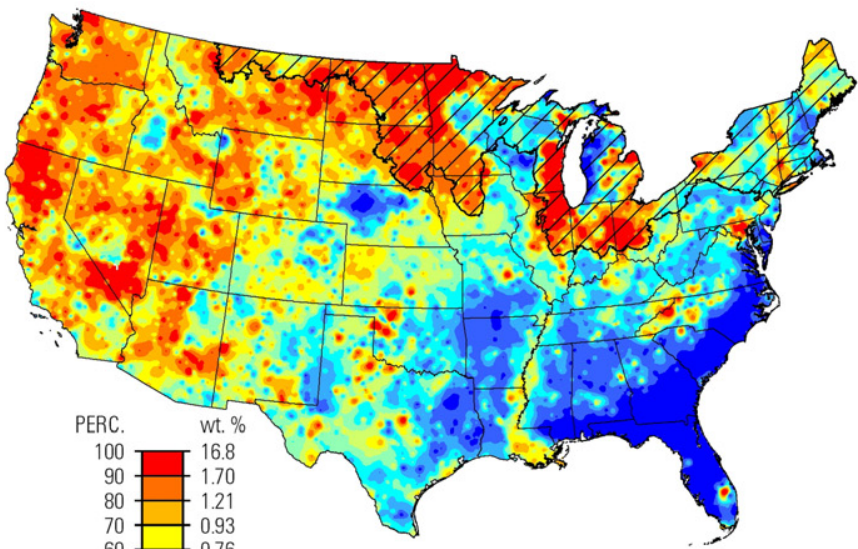

D. Magnesium (Mg) - C Horizon

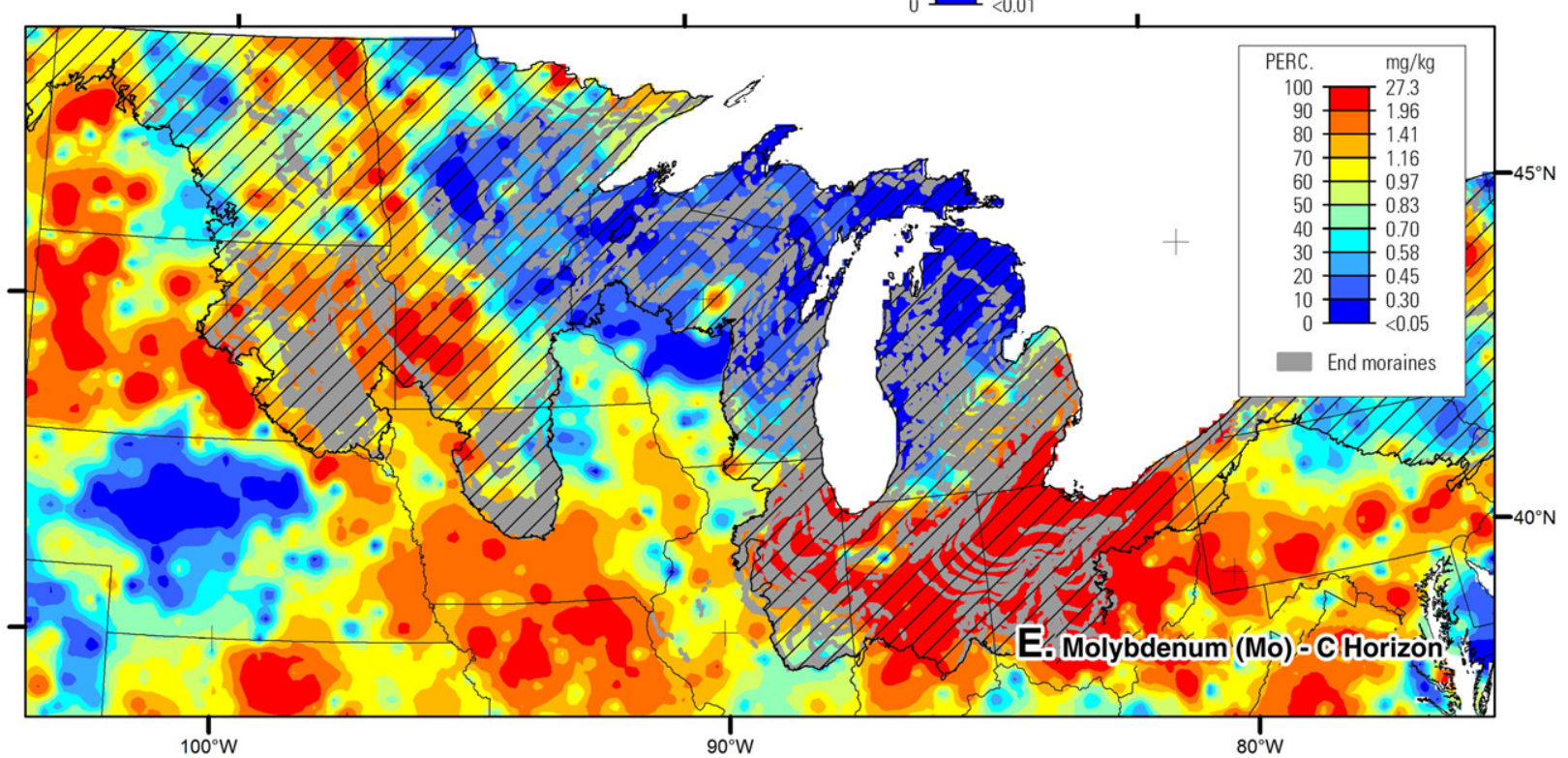

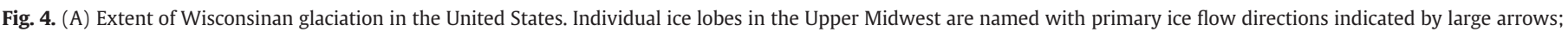

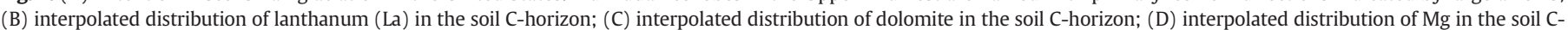

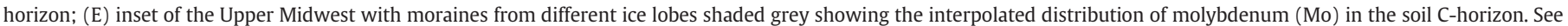
index map in Fig. 1A. Notation: Perc. = percentile; wt.\% = weight percent. Southern extent of glacial limit and distribution of glacial moraines from Soller et al. (2009). 


\subsection{Alluvial soil in the Lower Mississippi River Valley}

The Mississippi River and its tributaries drain a very large region covering about $37 \%$ of the conterminous United States. The lower reaches of the river south of its confluence with the Ohio River consist of broad alluvial plains and terraces composed of sediments eroded from a wide variety of geological materials upstream. Alluvial deposits are complex and reflect a history of waxing and waning of Pleistocene glaciers, and related sea level changes, during which these distal outwash deposits were laid down. Deposition continued throughout the Holocene to form the modern flood plains. Loess was deposited through Quaternary and Recent time when alluvium dried and was picked up by
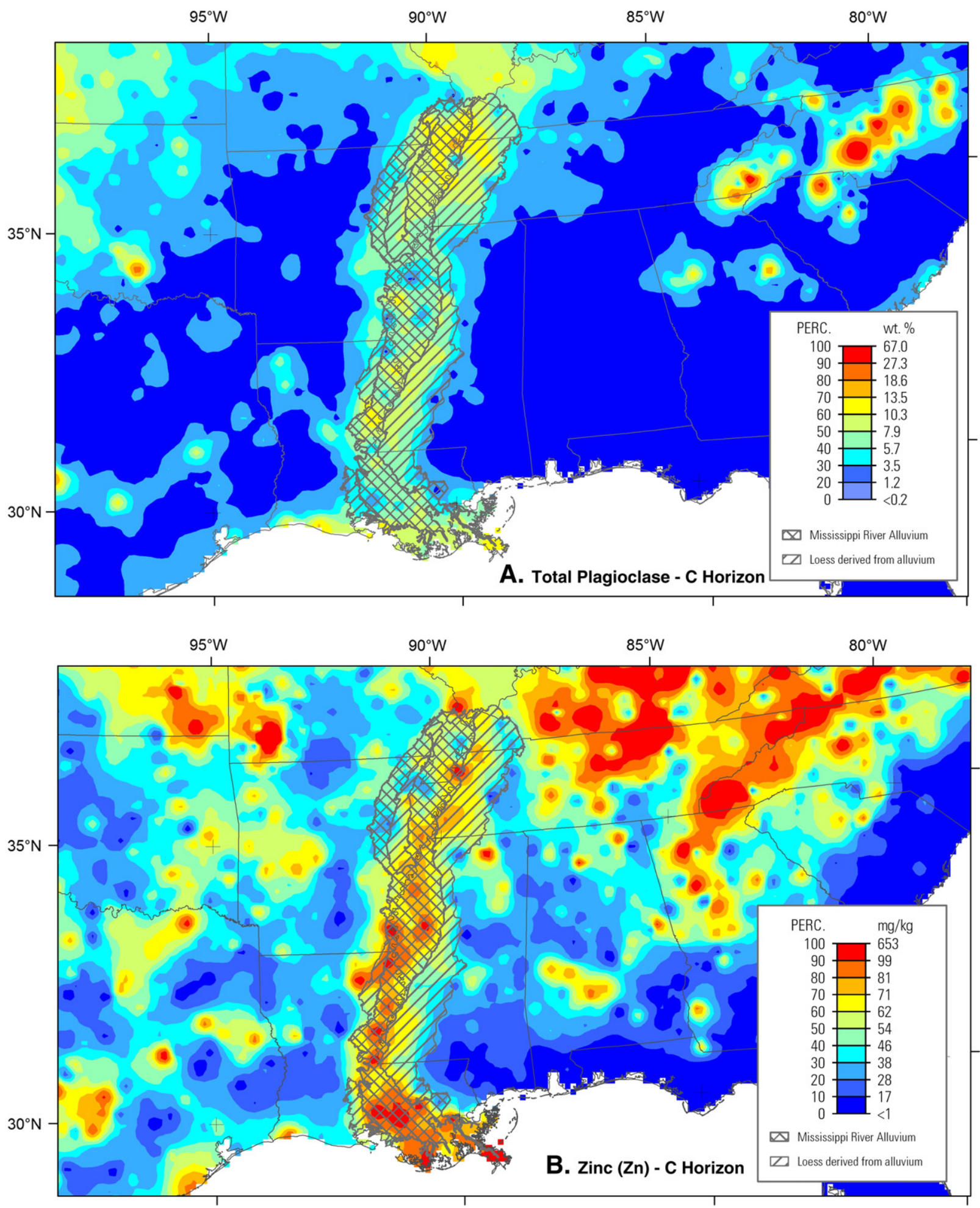

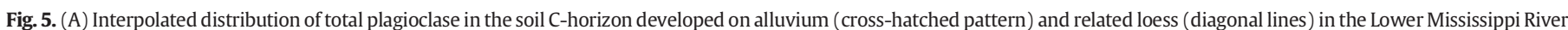

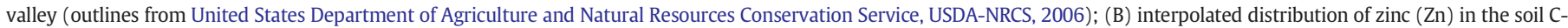

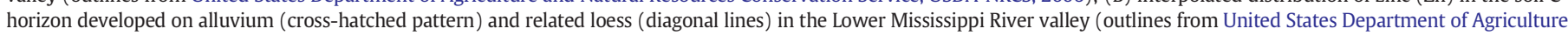

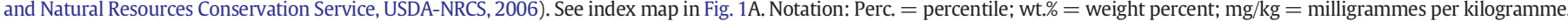


westerly winds, mantling upland Coastal Plain soil mostly east of the river valley. Most of the soil derived from Mississippi River alluvium and loess has chemical and mineralogical signatures more akin to sources in glaciated or loess-mantled regions to the north than to the immediately adjacent soil east and west of the river valley, which is largely quartz-rich Coastal Plain soil. The Mississippi River alluvial soil is an example of long-distance transport of material in a major river system to produce a region of soil composition on the alluvial plains
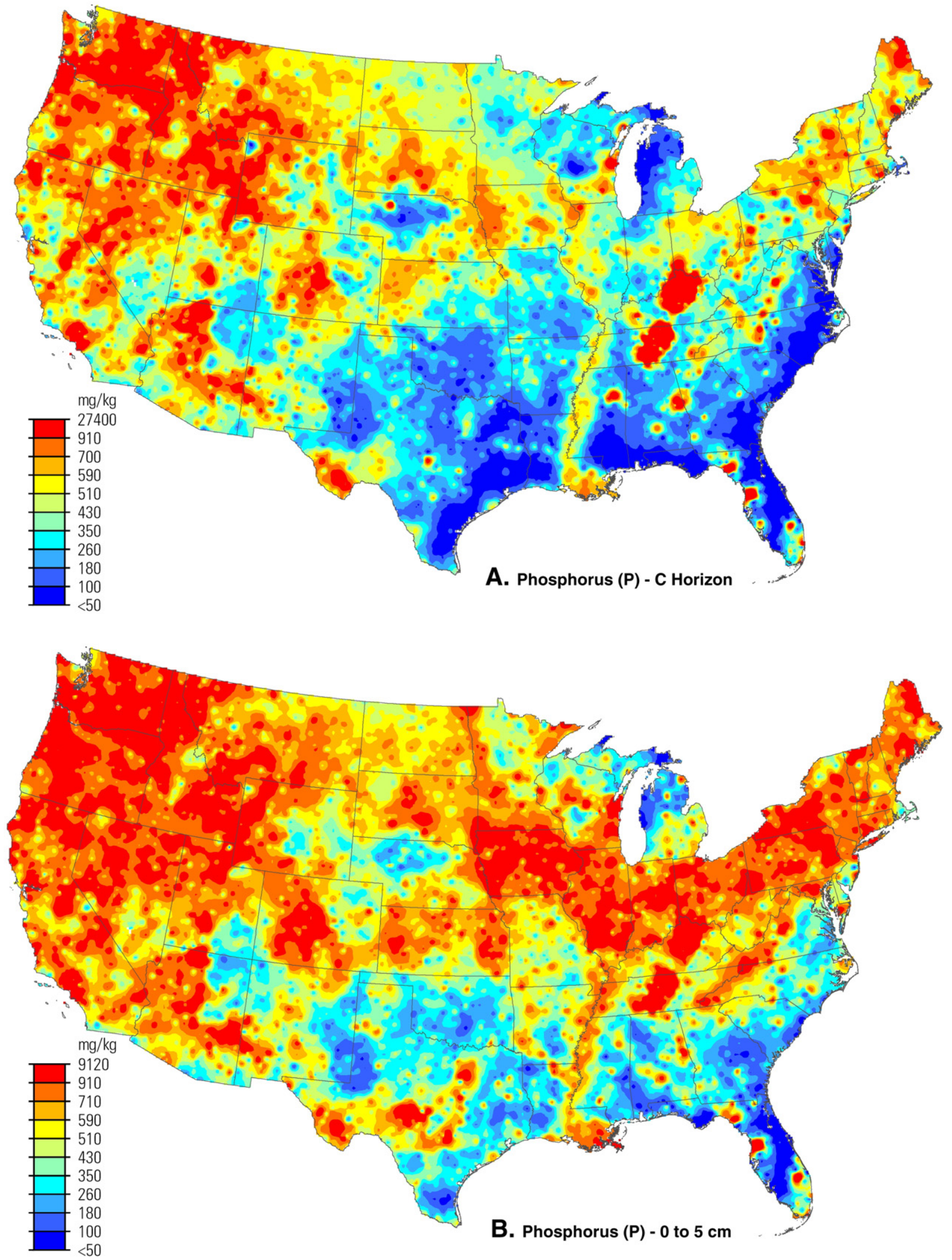

Fig. 6. (A) Interpolated distribution of phosphorus (P) in the soil C-horizon; (B) interpolated distribution of phosphorus (P) in the top $5 \mathrm{~cm}$ of soil. 
that is exotic to the surrounding areas. Total plagioclase and $\mathrm{Zn}$ in the soil C-horizon are two good examples among many that show this relationship and the prominent trace of the lower Mississippi River Valley (Fig. 5A, B).

\subsection{Possible anthropogenic impacts - phosphorus and lead}

Soil element concentrations are highly variable across the conterminous United States, reflecting not only the natural variations expected across so many gradients of soil-forming factors, but also a wide range of human activities. Assuming that loading of elements to surface soil reflects human inputs, it is possible to evaluate anthropogenic impact to soil by comparing element concentrations in surface soil to concentrations in deeper soil at individual sites. Such comparisons can be complicated by the potential of multiple parent lithologies at a site, such as a loess mantle or strong vertical variations in mineralogy but, in general, higher concentrations in surface soil versus deeper soil supporting surface loading.

\subsubsection{Phosphorus}

The distribution of $\mathrm{P}$ in the soil C-horizon generally reflects the presence or absence of P-bearing minerals in soil parent material. In Kentucky and Tennessee, where soil has developed on weathered Ordovician limestone that contains residual microcrystalline apatite (Cressman and Peterson, 1986), soil is naturally high in P, with the highest measured value of $27,400 \mathrm{mg} / \mathrm{kg}$ occurring in a soil C-horizon sample from Kentucky (Fig. 6A). However, the regional pattern for $\mathrm{P}$ in the soil A-horizon across the Midwest suggests possible loading of $P$ to top soil (Fig. 6B). Soil was analysed for total P, so it is not possible to differentiate among the many P species (for example, plant soluble vs. insoluble) that may have been present at the time of collection. Possible anthropogenic loading to soil was evaluated by comparing $\mathrm{P}$ concentrations in surface soil to concentrations in deeper soil at sites from four states in the Upper Midwest (Indiana, Illinois, Iowa, and Minnesota), where agriculture (including cultivated cropland and pasture/hay) was the dominant land use/land cover classification. Land use/land cover categories for non-agricultural sites included forested and herbaceous uplands. Land use/land cover information was taken from field notes. The median P values for soil collected from agricultural sites $(\mathrm{n}=276)$ are: 0 to $5 \mathrm{~cm}$ depth sample, $830 \mathrm{mg} / \mathrm{kg}$ P; soil A-horizon, $750 \mathrm{mg} / \mathrm{kg}$ P; soil C-horizon, $470 \mathrm{mg} / \mathrm{kg}$ P. For nonagricultural sites $(\mathrm{n}=96)$, the median $P$ values are: 0 to $5 \mathrm{~cm}$ depth sample, $535 \mathrm{mg} / \mathrm{kg} \mathrm{P}$; soil A-horizon, $520 \mathrm{mg} / \mathrm{kg}$ P; and soil C-horizon, $380 \mathrm{mg} / \mathrm{kg}$ P. These higher concentrations of $\mathrm{P}$ in agricultural soil may be attributed to incorporation of plant residues, and/or application of phosphate fertilisers or manure. This type of $P$ imbalance between top soil and deeper soil is consistent with patterns noted for many countries where $P$ accumulation in agricultural soil is attributed to inputs of fertiliser in excess of outputs in agricultural products (Bennett et al., 2001; De Vos and Tarvainen, 2006; Reimann et al., 2003; Salminen et al., 2005). Soil texture and mineralogy may have a role in $\mathrm{P}$ retention as agricultural soil is more clay-rich (medians for the soil

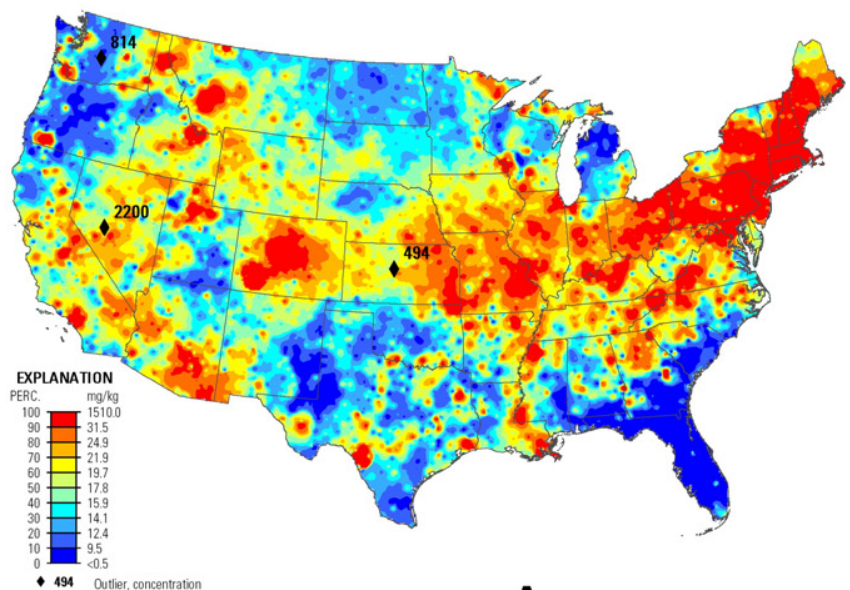

A. Lead (Pb) - A Horizon

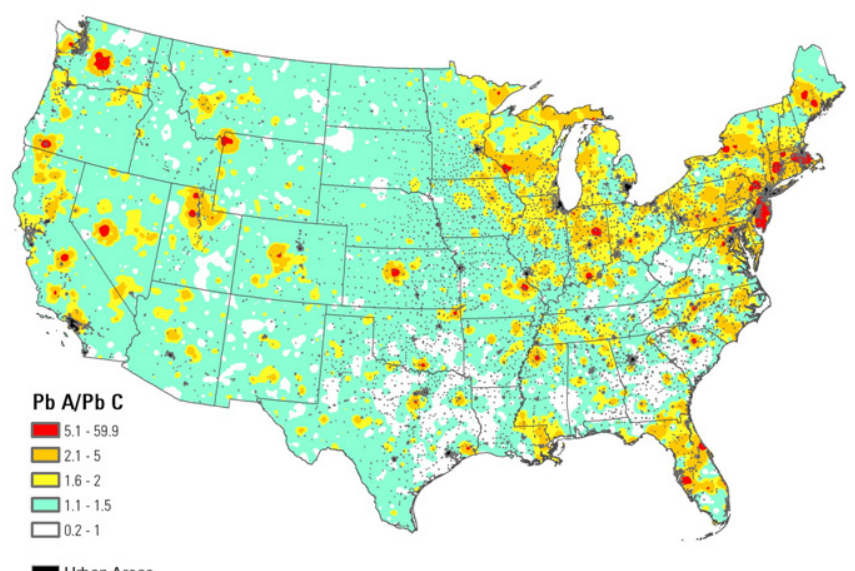

C. Lead (Pb) - Ration of A Horizon/C Horizon

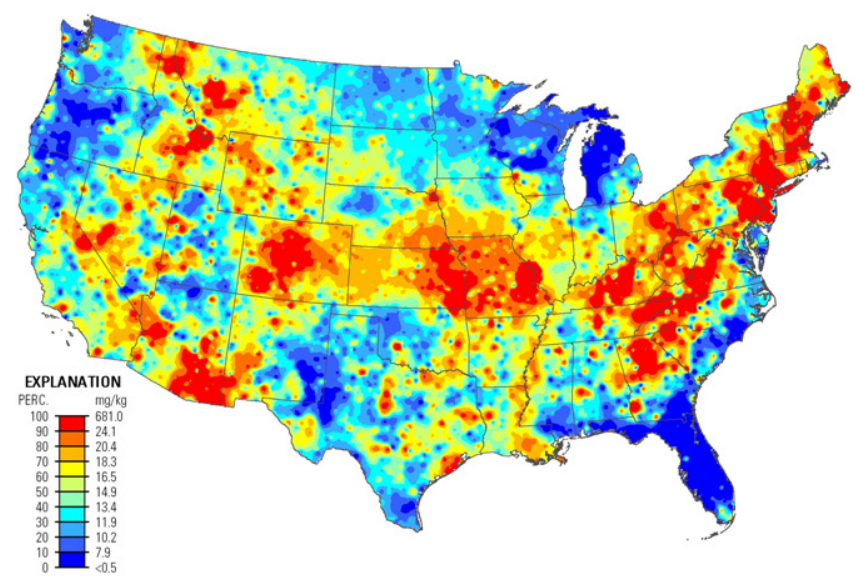

B. Lead (Pb) - C Horizon

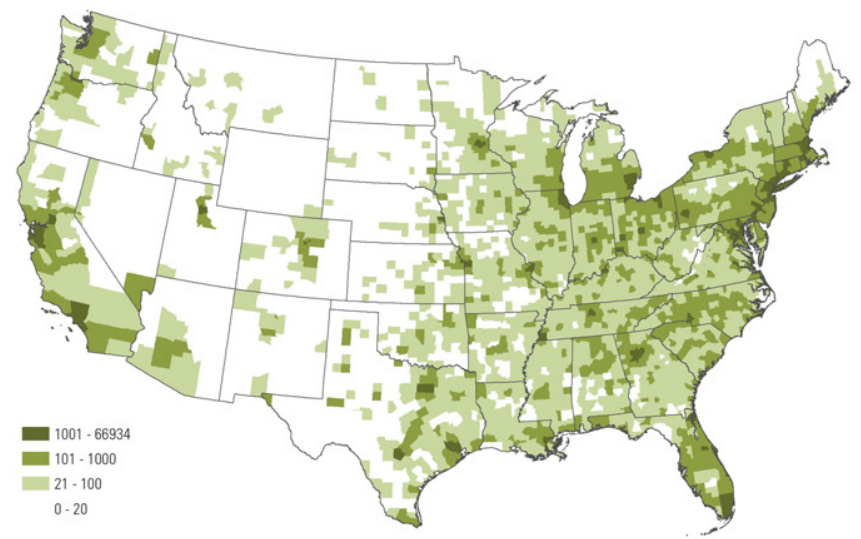

D. Population density (per sq. mile) by country

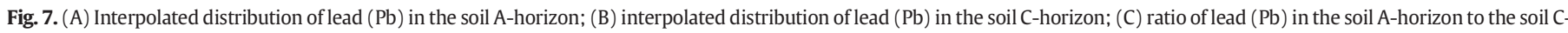
horizon; (D) population density by county of the conterminous United States (NationalAtlas.gov). Notation: Perc $=$ percentile; $\mathrm{mg} / \mathrm{kg}=\mathrm{milligrammes}$ per kilogramme. 
A- and C-horizons are $10.2 \mathrm{wt} . \%$ and $11.2 \mathrm{wt} . \%$, respectively) than nonagricultural soil (medians for the soil A- and C-horizons are $5.4 \mathrm{wt} . \%$ and $6.6 \mathrm{wt} . \%$, respectively).

\subsubsection{Lead}

Lead is another of the handful of elements in the soil data that exhibits enrichment in near-surface soil relative to the soil C-horizon at many of sample sites. The distribution of $\mathrm{Pb}$ in the soil A- and Chorizons is given in Fig. 7A and B. Values for the soil C-horizon primarily represent geogenic background $\mathrm{Pb}$ concentrations in soil parent materials, including both underlying bedrock and unconsolidated deposits. An interpolation of $\mathrm{Pb}$ in the soil A-horizon divided by $\mathrm{Pb}$ in the soil C-horizon is given in Fig. 7C, which indicates that the Pb concentration of the soil A-horizon is generally at least slightly higher than that of the soil C-horizon. Based on these data, soil across much of the conterminous United States can have up to 1.5 times greater $\mathrm{Pb}$ concentration in near-surface soil compared to deeper soil, and substantial areas have soil A-horizon enrichments of 1.5 or greater. Locally, $\mathrm{Pb}$ enrichment in the soil A-horizon can exceed a factor of five. Areas of known $\mathrm{Pb}$ mineralisation and mining, such as central Colorado and south-east Missouri, are apparent in both the soil A- and C-horizons; however, it is suggested that much of the large-scale pattern of relative $\mathrm{Pb}$ enrichment in the soil A-horizon might be caused by additions of $\mathrm{Pb}$ from widespread anthropogenic sources, such as the combustion of leaded petrol, a once common practice that was phased out in the United States in the 1970s. Whereas some areas of surface enrichment occur in areas of low population density, such as northern California, northern Michigan, and northern Minnesota, while many areas of $\mathrm{Pb}$ enrichment in the soil A-horizon correspond to areas of high population density, particularly in the populous, urbanised/industrialised north-eastern United States (Fig. 7D). There are no known geological factors that could account for such enrichment in the soil A-horizon, and suggest that anthropogenic $\mathrm{Pb}$ addition should be considered among the possibilities for this pattern. Further interpretation of soil $\mathrm{Pb}$ patterns across the country is warranted.

\section{Conclusions}

Spatial differences in soil geochemistry and mineralogy at regional and continental scales can be attributed to distinctive soil parent materials modified by climate-related processes, such as weathering (driven by continent-wide gradients of temperature and precipitation), and glaciation. Soil mineralogy exerts control on both soil chemical and physical properties. Quantitative mineralogy, allied with elementconcentrations, allows inference of mineralogical hosts for many major and trace elements. Element distribution, among the multiple soil samples collected from each site, provides indications of possible human influences superimposed on natural soil background concentrations. This recently completed USGS project to map the soil geochemistry and mineralogy of the conterminous United States provides a three-dimensional framework for understanding the processes that cause observed distribution of chemical elements and minerals in soil in this part of North America.

\section{Acknowledgements}

Many people contributed to the success of this endeavour, including the large number who participated in the design of the project, the long list of people who collected the samples across the country, the USGS employees who completed the sample preparation and mineralogical analyses, and the many generous private landowners who gave the USGS permission to collect soil on their properties.

\section{References}

Bennett, E.M., Carpenter, S.R., Caraco, N.F., 2001. Human impact on erodible phosphorus and eutrophication: a global perspective. Bioscience 52, 227-234.

Bern, C.R., 2009. Soil chemistry in lithologically diverse datasets: the quartz dilution effect. Appl. Geochem. 24, 1429-1437.

Cressman, E.R., Peterson, W.L., 1986. Ordovician system. In: McDowell, R.C. (Ed.), The Geology Of Kentucky: A Text To Accompany The Geologic Map Of Kentucky. U.S. Geological Survey Professional Paper 1151-H (http://pubs.usgs.gov/pp/p1151h/contents. html).

De Vos, W., Tarvainen, T., 2006. Geochemical Atlas Of Europe. Part 2 - Interpretation Of Geochemical Maps, Additional Tables, Figures, Maps And Related Publications. Geological Survey Of Finland, Espoo, Finland. In: Salminen, R., Reeder, S., De Vivo, B., Demetriades, A., Pirc, S., Batista, M.J., Marsina, K., Ottesen, R.T., O'Connor, P.J., Bidovec, M., Lima, A., Siewers, U., Smith, B., Taylor, H., Shaw, R., Salpeteur, I., Gregorauskiene, V., Halamic, J., Slaninka, I., Lax, K., Gravesen, P., Birke, M., Breward, N., Ander, E.L., Jordan, G., Duris, M., Klein, P., Locutura, J., Bel-lan, A., Pasieczna, A., Lis, J., Mazreku, A., Gilucis, A., Heitzmann, P., Klaver, G., Petersell, V. (Eds.), (692 pp., http://weppi.gtk.fi/publ/foregsatlas/).

Demetriades, A., Reimann, C., Filzmoser, P., 2014. Evaluation of GEMAS project quality control results. In: Reimann, C., Birke, M., Demetriades, A., Filzmoser, P., O'Connor, P. (Eds.), Chemistry Of Europe's Agricultural Soils - Part A: Methodology And Interpretation Of The GEMAS Data Set Geologisches Jahrbuch (Reihe B102), Schweizerbarth, Hannover, pp. 47-60 (Chapter 6).

Dreele, R.B., 1997. Quantitative texture analysis by Rietveld refinement. J. Appl. Crystallogr. 30 (4), 517-525.

Dyke, A.S., Andrews, J.T., Clark, P.U., England, J.H., Miller, G.H., Shaw, J., Veillette, J.J., 2002. The Laurentide and Innuitian ice sheets during the last glacial maximum. Quat. Sci. Rev. 21, 9-31.

Fenneman, N.M., Johnson, D.W., 1946. Physical divisions of the United States: U.S. Geological Survey map prepared in cooperation with the Physiographic Commission, scale 1: 700,000 (reprinted in 1964)

Friske, P.W.B., Rencz, A.N., Ford, K.L., Kettles, I.M., Garrett, R.G., Grunsky, E.C., McNeil, R.J., Klassen, R.A., 2013. Overview of the Canadian component of the North American Soil Geochemical Landscapes Project with recommendations for acquiring soil geochemical data for environmental and human health risk assessments. Geochem. Explor. Environ. Anal. 13, 267-283.

Garrett, R.B., 2009. Relative spatial soil geochemical variability along two transects across the United States and Canada. Appl. Geochem. 24, 1405-1415.

Hofer, J.W., Szabo, J.P., 1993. Port Bruce ice-flow directions based on heavy-mineral assemblages in tills from the south shore of Lake Erie in Ohio. Can. J. Earth Sci. 30, $1236-1241$.

Jenny, H., 1941. Factors Of Soil Formation. McGraw-Hill Book Company, Inc., New York, New York, USA (281 pp.).

Johnson, W.H., 1986. Stratigraphy and correlation of the glacial deposits of the Lake Michigan lobe prior to 14 ka BP. Quat. Sci. Rev. 5, 17-22.

Markevich, H.W., Pavich, M.J., Buell, G.R., 1990. Contrasting soils and landscapes of the Piedmont and Coastal Plain, eastern United States. Geomorphology 3, 417-447.

McCusker, L.B., Von Dreele, R.B., Cox, D.E., Louër, D., Scardi, P., 1999. Rietveld refinement guidelines. J. Appl. Crystallogr. 32 (1), 36-50.

Mickelson, D.M., Colgan, P.M., 2003. The southern Laurentide Ice Sheet. Dev. Quat. Sci. 1, $1-16$.

Reimann, C., Siewers, U., Tarvainen, T., Bityukova, L., Eriksson, J., Gilucis, A., Gregorauskiene, V., Lukashev, V.K., Matinian, N.N., Pasieczna, A., 2003. Agricultural soils in Northern Europe: a geochemical atlas. E. Schweizerbart'sche Verlagsbuchhandlung, Stuttgart (279 pp.).

Reimann, C., Filzmoser, P., Garrett, R.G., Dutter, R., 2008. Statistical Data Analysis Explained. John Wiley \& Sons, Chichester, UK (343 p.).

Reimann, R., Demetriades, A., Eggen, O.A., Filzmoser, P., The EuroGeoSurveys Geochemistry Expert Group, 2009. The EuroGeoSurveys geochemical mapping of agricultural and grazing land soils project (GEMAS) - Evaluation of quality control results of aqua regia extraction analysis. Geological Survey of Norway, Trondheim, NGU report 2009.049. http://www.ngu.no/upload/Publikasjoner/Rapporter/2009/ 2009_049.pdf (94 pp.).

Reimann, C., Demetriades, A., Eggen, O.A., Filzmoser, P., the EuroGeoSurveys Geochemistry Expert Group, 2011. The EuroGeoSurveys GEochemical Mapping of Agricultural and grazing land Soils project (GEMAS) - Evaluation of quality control results of total $C$ and $S$, total organic carbon (TOC), cation exchange capacity (CEC), $\mathrm{XRF}, \mathrm{pH}$, and particle size distribution (PSD) analysis. Geological Survey of Norway, Trondheim, NGU report 2011.043. http://www.ngu.no/upload/Publikasjoner/ Rapporter/2011/2011_043.pdf (90 pp.).

Reimann, C. Demetriades, A, Birke, M. Eggen, O.A, Filzmoser, P., Kriete, C. EuroGeoSurveys Geochemistry Expert Group, 2012. The EuroGeoSurveys Geochemical Mapping of Agricultural and grazing land Soils project (GEMAS) - Evaluation of quality control results of particle size estimation by MIR prediction, $\mathrm{Pb}$-isotope and MMI® extraction analyses and results of the GEMAS ring test for the standards Ap and Gr. Geological Survey of Norway, Trondheim, NGU report 2012.051. http:// www.ngu.no/upload/Publikasjoner/Rapporter/2012/2012_051.pdf (136 pp.).

Reynolds, R., Neff, J., Reheis, M., Lamothe, P., 2006. Atmospheric dust in modern soil on aeolian sandstone, Colorado Plateau (USA): variation with landscape position and contribution to potential plant nutrients. Geoderma 130, 108-123.

Sakata, M., Cooper, M.J., 1979. An analysis of the Rietveld refinement method. J. Appl. Crystallogr. 12 (6), 554-563.

Salminen, R., Batista, M.J., Bidovec, M., Demetriades, A., De Vivo, B., De Vos, W., Duris, M., Gilucis, A., Gregorauskiene, V., Halamic, J., Heitzmann, P., Lima, A., Jordan, G., Klaver, G., Klein, P., Lis, J., Locutura, J., Marsina, K., Mazreku, A., O'Connor, P.J., Olsson, S.Å., 
Ottesen, R.T., Petersell, V., Plant, J.A., Reeder, S., Salpeteur, I., Sandström, H., Siewers, U., Steenfelt, A., Tarvainen, T., 2005. FOREGS Geochemical Atlas of Europe, Part 1: Background Information, Methodology and Maps. Geological Survey of Finland, Espoo. http://weppi.gtk.fi/publ/foregsatlas/ (526 pp.).

Smith, D.B., Woodruff, L.G., O'Leary, R.M., Cannon, W.F., Garrett, R.G., Kilburn, J.E., Goldhaber, M.B., 2009. Pilot studies for the North American Soil Geochemical Landscapes Project-site selection, sampling protocols, analytical methods, and quality control protocols. Appl. Geochem. 24, 1357-1368.

Smith, D.B., Cannon, W.F., Woodruff, L.G., 2011. A national-scale geochemical and mineralogical survey of soils of the conterminous United States. Appl. Geochem. 26, S250-S255 (Supplement).

Smith, D.B., Cannon, W.F., Woodruff, L.G., Rivera, F.M., Rencz, A.N., Garrett, R.G., 2012. History and progress of the North American Soil Geochemical Landscapes Project, 2001-2010. Earth Sci. Front. 19, 19-32.

Smith, D.B., Smith, S.M., Horton, J.D., 2013a. History and evaluation of national-scale geochemical data sets for the United States. Geosci. Front. 4, 167-183.

Smith, D.B., Cannon, W.F., Woodruff, L.G., Solano, Federico, Kilburn, J.E., Fey, D.L., 2013b. Geochemical and mineralogical data for soils of the conterminous United States. U.S. Geological Survey Data Series 801. http://pubs.usgs.gov/ds/801/ (19 pp.).
Smith, D.B., Cannon, W.F., Woodruff, L.G., Solano, Federico, Ellefsen, K.J., 2014 Geochemical and mineralogical maps for soils of the conterminous United States. U.S. Geological Survey Open-File Report 2014-1082. http://pubs.usgs.gov/of/2014/ 1082/ (386 pp.).

Soller, D.R., Reheis, M.C., Garrity, C.P., Van Sistine, D.R., 2009. Map database for surficial materials in the conterminous United States. U.S. Geological Survey Data Series 425, scale $1: 5,000,000$.

Stevens Jr., D.L., Olsen, A.R., 2003. Variance estimation for spatially balanced samples of environmental resources. Environmetrics 14, 593-610.

Stevens Jr., D.L., Olsen, A.R., 2004. Spatially balanced sampling of natural resources. J. Am. Stat. Assoc. 99, 262-278.

Tuttle, M.L.W., Breit, G.N., Goldhaber, M.B., 2009. Weathering of the New Albany Shale, Kentucky: II. Redistribution of minor and trace elements. Appl. Geochem. 24, 1565-1578.

United States Department of Agriculture, Natural Resources Conservation Service (USDA NRCS), 2006. Land resource regions and major land resource areas of the United States, the Caribbean, and the Pacific Basin. U.S. Department of Agriculture Handbook. 296 (682 pp.) 